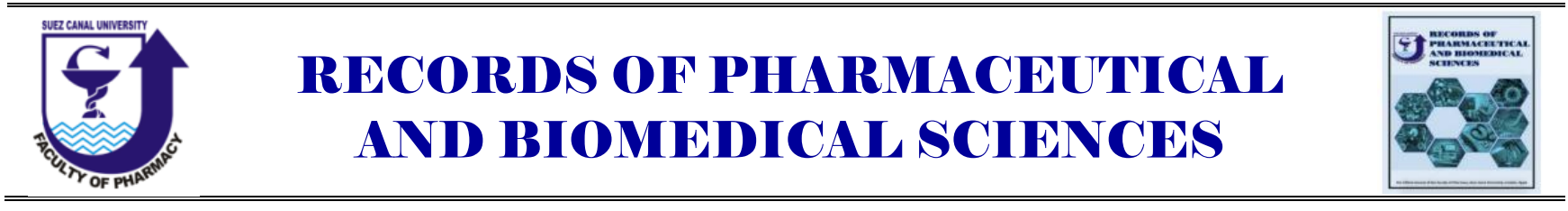

\title{
Recent Updates in Treatment of Diabetic Neuropathy
}

\author{
Mangreed M. Atef ${ }^{a}$, Norhan M. El-Sayed ${ }^{b}$, Amal A.M. Ahmed ${ }^{\mathrm{c}}$, Yasser M. Mostafa ${ }^{\mathrm{b}}$
}

${ }^{a}$ Suez Canal University Teaching Hospitals, Ismailia, Egypt,${ }^{b}$ Department of Pharmacology \& Toxicology, Faculty of Pharmacy, Suez Canal University, Ismailia 41522, Egypt, ${ }^{c}$ Department of Cytology \& Histology, Faculty of Veterinary Medicine, Suez Canal University, Ismailia, Egypt.

Received on: 29.04. 2019

Revised on: 15. 05. 2019

Accepted on: 20. 05. 2019

Correspondence Author:

Tel:+ 01221559921

E-mail address:

Mangreed_Atef@hotmail.com

\begin{abstract}
Diabetic neuropathy (DN) is the most common microvascular complication which progressively leads to neuronal degeneration. Consequently, DN is associated with sensory symptoms such as pain, numbness, tingling, pins and needles, prickling and pinching and eventually loss of sensation. Symptoms are considered moderate to severe and may worsen at night, causing sleeping disturbs. Neuropathic pain can be constant and accompanied by cutaneous allodynia, which can affect the performance of daily activities of diabetic patients. The mechanisms that cause diabetic neuropathic pain (DNP) are not fully understood, although toxic effects of hyperglycaemia considered an important factor for the development of this complication.
\end{abstract}

Keywords: Diabetic Neuropathy, Physiopathology, Oxidative and Nitrosative Stress.

\section{Diabetic Neuropathy}

Diabetic neuropathy (DN) is the most common microvascular complication which progressively leads to neuronal degeneration. Consequently, DN is associated with sensory symptoms such as pain, numbness, tingling, pins and needles, prickling and pinching and eventually loss of sensation. Symptoms are considered moderate to severe and may worsen at night, causing sleeping disturbs (Schreiber et al., 2015).

Neuropathic pain can be constant and accompanied by cutaneous allodynia, which can affect the performance of daily activities of diabetic patients (Quattrini and Tesfaye, 2003).

\section{Physiopathology of Neuropathic Pain in Diabetes}

The mechanisms that cause diabetic neuropathic pain (DNP) are not fully understood, although toxic effects of hyperglycaemia considered an important factor for the development of this complication (Oyibo et al., 2002).

\section{Polyol pathway hyperactivity}

Metabolic disorders are the main reason for DN. Hyperglycaemia, produced as a result of decreasing in insulin secretion or insulin resistance, is responsible for the boosted of the polyol pathway activity. The formation of sorbitol from glucose with the oxidation of nicotinamide adenine dinucleotide phosphate (NADPH) to $\mathrm{NADP}^{+}$is catalyzed by aldose reductase enzyme. Furthermore, Sorbitol is oxidized to fructose by sorbitol dehydrogenase enzyme, which is coupled with the reduction of nicotinamide adenine dinucleotide $\left(\mathrm{NAD}^{+}\right)$to $\mathrm{NADH}$. In diabetic patients, aldose reductase has a greater affinity for glucose, that leads to the 
accumulation of sorbitol which doesn't cross cell membranes causing intracellular osmotic stress (Oates, 2002; Sheetz and King, 2002). However, the present hypothesis states that polyol pathway hyperactivity is pathogenic due to increase in the turnover of cofactors such as NADPH and NAD ${ }^{+}$, which leads to a decrease in the reduction and regeneration of glutathione. In addition, an increase of advanced glycation end products (AGEs) production and activation of diacylglycerol and protein kinase $\mathrm{C}$ (PKC) isoforms are involved. Glutathione depletion could be the primary cause of oxidative stress and be related to the accumulation of toxic species (Oates, 2002). In fact, aldose reductase inhibitors could be effective in preventing the development of DN in animal models, but they have demonstrated disappointing results and doselimiting toxicity in human trials (Chalk et al., 2007).

\section{Oxidative and Nitrosative Stress}

As previously mentioned, the primary cause of oxidative stress associated with diabetes is due to polyol pathway activation. However, oxidative stress could be caused by a) Autoxidation of glucose and its metabolites. b) The intracellular formation of AGEs and augmentation of its activating ligands. c) Changes in mitochondrial function. d) Activation of PKC isoforms.

e) over activity of the hexosamine pathway (Brownlee, 2001).

Besides oxidative stress, reactive nitrogen species, particularly the peroxynitrite also play a vital role in the development of diabetes and its complications (Obrosova et al., 2005; Vareniuk et al., 2007).

Though it has been obviously demonstrated significant changes in oxidative status in diabetic animal models (Cunha et al., 2008), tissue concentrations of known carbonyl compounds are nearly insignificant. The plasma ET-1, nitric oxide, catalase and glutathione levels are almost the same in neuropathic diabetic patients compared to nonneuropathic diabetic ones (Ozkul et al., 2010).

In line with this observation, clinical results have been conflicting for antioxidants as alpha lipoic acid, ranging from little benefit (Mijnhout et al., 2010; Ziegler et al., 2011) to meaningful advantages (Tang et al., 2007).

\section{Microvascular changes}

DN is frequently associated with microvascular impairment (Arora et al., 2002; Doupis et al., 2009). In clinical and preclinical studies, a reduction in peripheral perfusion in the nervous tissue (Cameron et al., 2001), and also in the skin was observed (Jin et al., 2012). This can be considered as an important physiological evidence of microvasculature alteration.

Nerve ischemia occurs as a result of increases in wall thickness and hyalinization of the basal lamina of vessels that supply peripheral nerves (Malik et al., 1993; Pavy-Le Traon et al., 2010), together with luminal reduction (Malik et al., 1993). These changes are caused by plasma protein escape of the capillary membrane to endoneurium, inducing swelling and increase in interstitial pressure in the nerves, accompanied by higher capillary pressure, sedimentation of fibrin and thrombus development. Hyperglycaemia can trigger nerve hypoxia, especially in sensory nerves, changing their electrical stability (Fuchs et al., 2010). Apparently argumentative data from clinical studies described that diabetic patients suffering from the DNP had a significant difference of levels of intravascular oxygen and increases blood flow in the lower limbs than painless patients. Though, authors still consider a hypoxic state inside the endoneurium. Otherwise, a potential sympathetic dysfunction can be the cause of higher blood flow (Eaton et al., 2003).

Both diabetic patients and animals have shown a progressive nerve loss in proximal and distal segments (Jelicic Kadic et al., 2014; Shun et al., 2004), That cause a reduction of intraepidermal nerve fibre density (Sorensen et al., 2006). Consequently, axonal degeneration and regeneration occur frequently in asymptomatic patients. Besides axonal retraction and regeneration, myelin sheath alteration related to hyperglycaemia are detected. The observed demyelination can be related to Schwann cells altered capacity to support normal myelin sheath (Said et al., 2008).

The endothelial function in diabetic patients with neuropathy is also altered. The vasodilatation induced by acetylcholine (i.e., the endotheliumdependent response) in dermal vessels of diabetic patients is reduced in comparison with nondiabetic subjects. In addition, vasoconstriction mediated by the sympathetic system (i.e., endothelium-independent response) 


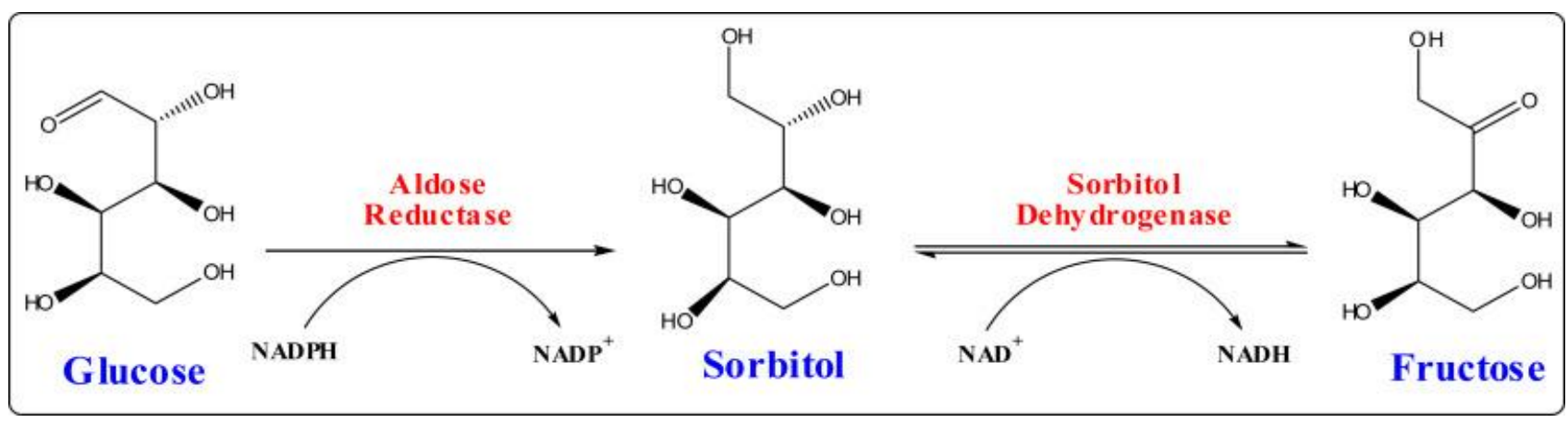

Figure 1. The polyol metabolic pathway. The pathway contains aldose reductase and sorbitol dehydrogenase enzymes. It plays a vital role in the development of diabetic complications.

is also defective, which can also be involved in the pathophysiology of $\mathrm{DN}$ and then, in the DNP (Quattrini et al., 2007).

The oxidative stress as described above may cause the microvascular changes, although treatment with antioxidant agents can retain regular perfusion, restoring the sensory transmission in type 1 diabetic model (Inkster et al., 2007).

\section{Microglial activation}

Glial cells play an essential role in the pathogenesis of many diseases of the nervous system, including chronic pain states. Glia consist of both macroglia (including astrocytes, radial cells and oligodendrocytes) and microglia cells, which are mainly responsible for maintain homeostasis, form myelin, and provide support and protection for neurons from both central and peripheral nervous system (Mika et al., 2013).

Microglial cells cover less than 20\% of spinal glial cells but there is a vigorous proliferation at spinal level in response to dorsal root ganglia and spinal cord after nerve injury (Kettenmann and Verkhratsky, 2008). Activation of microglia arises immediately after peripheral nerve injury, lasting for less than 3 months, and is responsible for a production of several inflammatory mediators as cytokines, chemokines, and cytotoxic substances such as nitric oxide and free radicals, leading to a pro inflammatory milieu (Vydyanathan et al., 2005).

Diabetes has effect on all glial cells of the spinal cord since chronic microglial activation was detected in streptozotocin-induced diabetic rats lasting from 4 weeks (Tsuda et al., 2008; Wodarski et al., 2009) to 6 or 8 months (Cheng et al., 2014; Toth et al., 2010). This microglial activation has been related with sensorial changes and up-regulation of Nav1.3 sodium channels in the dorsal root ganglia (DRG) (Cheng et al., 2014), possible through p38 mitogen activated protein kinase dependent mechanism (Crown, 2012; Suzuki et al., 2011).

On the other hand, diabetes is associated with a reduction in glial fibrillary acidic protein (i.e., glial fibrillary acidic protein) immunoreactive astrocytes in the spinal cord, which may influence the functional support and role of astrocytic cells in the nervous tissue, such as the clearance of neurotransmitters within the synaptic cleft (Afsari et al., 2008).

\section{Central sensitization}

Diabetic neuropathic pain (DPN) may be a consequence of both peripheral and central nervous system (CNS) changes (Chen and Pan, 2002; Maier et al., 2010). During DNP, primary afferents are sensitized, inducing dorsal horn hyperactivity and neuroplastic alters in central sensory neurons (Chen and Pan, 2002). The common occurrence of allodynia in DNP patients is due to changes in CNS pain processing (Aslam et al., 2014).

The increased glutamate release from primary afferents in the spinal cord in DN can lead to the hyperactivity of spinal neurons (Li et al., 2010; Wang et al., 2007). Moreover, spinal N-Methyl$\mathrm{D}$-aspartate (NMDA) receptor expression is augmented (Bai et al., 2014), generating increased and more frequent excitatory postsynaptic currents in the lamina II (Wang et al., 2007). Moreover, it has been described that cAMP response element-binding protein signalling, which directly regulates NMDA receptors activity (Kim et al., 2012) , is enhanced in DNP (Bai et al., 2014; Sanchez and Sharma, 2009).

Enhanced spinal NMDA expression and glutamate release might contribute to spinal cord 
hyperactivity. On the other hand, metabotropic receptors for neurotransmitter $\gamma$-Aminobutyric Acid $\left(\mathrm{GABA}_{\mathrm{B}}\right)$ receptors are downregulated in the spinal cord in DN (Bai et al., 2014).

Activation of $\mathrm{GABA}_{\mathrm{B}}$ receptors causes inhibition of NMDA receptor activity by direct inhibition of voltage-sensitive $\mathrm{Ca}^{2+}$ channels (Pérez-Garci et al., 2006) and the opening of inwardly rectifying $\mathrm{K}^{+}$channels (Sodickson and Bean, 1996).

Additionally, the activation of $\mathrm{GABA}_{\mathrm{B}}$ receptor causes downregulation of NMDA receptors at the spinal level in diabetic rats (Bai et al., 2014).

Considering the significance of central sensitization in the hypersensitivity associated with DNP, targeted therapies that aim to control spinal neurons hyperexcitability are valuable in pain regulator in this condition, as will be discussed below.

\section{Adenosine monophosphate kinase (AMPK)}

AMPK (Adenosine monophosphate kinase) is a heterotrimeric Ser/Thr protein kinase is activated by changes in intracellular AMP: ATP ratio. Upon stimulation, AMPK inhibits energy consuming anabolic activities such as protein translation (Hardie, 2007). AMPK stimulation mediates these effects greatly via inhibition of mammalian target of rapamycin (mTOR) signalling (Hardie, 2007). AMPK activation has also been related to inhibition of mitogen activated protein kinase (MAPK) signaling (Kim et al., 2001; Melemedjian et al., 2011).

Several studies have suggested that AMP-activated protein kinase (AMPK) activators can reverse mechanical allodynia in neuropathic pain models and the ability of these compounds to negatively regulate protein synthesis in sensory afferents (Asiedu et al., 2016; Melemedjian et al., 2011; Wang et al., 2018).

AMPK activators such as metformin and A769662 decrease the excitability of DRG neurons (Melemedjian et al., 2011). Augmented excitability of these neurons after injury is widely assumed to cause higher activity result in burning pain that is a characterized feature of neuropathic pain (Baron et al., 2010). Although it still exhibited in vivo, the profound influence of AMPK activators on DRG excitability supposes that they might reverse mechanical hypersensitivity along with spontaneous pain related with persistent neuropathic pain in humans. Metformin might prevent neuropathic pain through AMPK pathway (Melemedjian et al., 2011). Metformin has been demonstrated to decrease mechanical allodynia in lumbar radiculopathy pain activated by spinal nerve ligation in rats and nerve injury in mice (Taylor et al., 2013). Thus, this suggest the neuroprotective effect of metformin on sensation and its potential in ameliorating neuropathic pain in diabetes mellitus.

Systemic administration of AMPK activators (either metformin or A769662) to rodents after peripheral nerve injury reduces mechanical hypersensitivity, results start 2-3 days after treatment (Melemedjian et al., 2011, 2013). Obviously, within 7 days, these compounds produced a total resolution of mechanical hypersensitivity that lasted even after discontinuation of treatment, confirming the idea that AMPK activators have disease-modifying properties that develop over the course of treatment.

\section{Mammalian Target of Rapamycin (mTOR)}

Mammalian target of rapamycin (mTOR) is considered as a serine and threonine protein kinase that triggers the various signals together to control the fundamental cellular functions such as induction of protein translation in addition to cell growth (McDaniel et al., 2002).

Mammalian target of rapamycin complex 1 (mTORC1) is regulated by upstream activation of tyrosine kinase receptors (Trks) and engagement of the phosphatidylinositol-3 kinase $(\mathrm{PI} 3 \mathrm{~K}) /$ protein kinase $\mathrm{B}(\mathrm{Akt})$ signaling. When mTORC1 is enhanced, it catalyses phosphorylation of a family of proteins that bind to the $5^{\prime}$ m7GTP Cap structure $\left(5^{\prime} \mathrm{Cap}\right)$ of mRNAs (Gingras et al., 2004).

In this process the phosphorylation of eukaryotic initiation factor (eIF) binding protein (BP) 4E$\mathrm{BP}$ is initiated when $4 \mathrm{E}-\mathrm{BP}$ is phosphorylated by mTORC1, 4E-BP dissociates from eIF4E, the $5^{\prime}$ cap binding protein, allowing for more efficient association of eIF4E with eIF4A (a deadbox family helicase) and eIF4G (a scaffolding protein) (Gingras et al., 2004). These three proteins create an efficient unit called the eIF4F complex. This eIF4F complex is linked to 


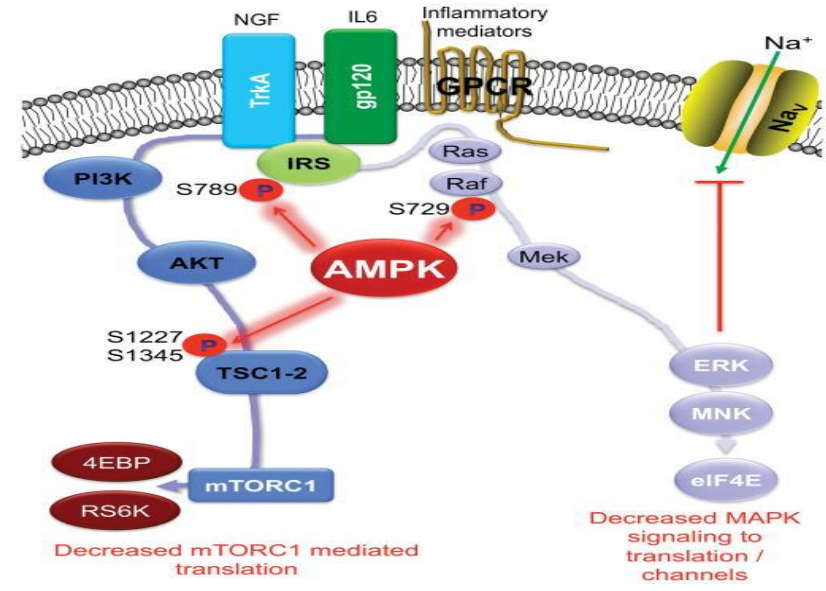

Figure 2. AMPK signaling pathways. regulation and downstream effects.

efficient translation of target messenger ribonucleic acid (mRNAs) and is a significant regulatory endpoint for mTORC1 signaling (Sonenberg, 2008). Increased mTORC1 activity is clearly linked to plasticity in nociceptors. First, rapamycin, a highly selective inhibitor of mTORC1, reduces plasticity enhanced by endogenous mediators that act via receptors expressed by nociceptive neurons (Melemedjian et al., 2010; Price et al., 2007). Also, rapamycin declines the sensitivity of a subset of nociceptors thought to play a vital role in mechanical hypersensitivity following injury (Géranton et al., 2009; Jiménez-Díaz et al., 2008) and reverses neuropathic mechanical hypersensitivity in rats (Melemedjian et al., 2013) and mice (Obara et al., 2011).

Control changes in synaptic strength between nociceptors and CNS neurons could be achieved by mTORC1 that transmits nociceptive information to the brain via alterations in postsynaptic expression of plasticity-related genes.

However, another explanation is that presynaptic effects in the dorsal roots, which contain the central projections of DRG neurons, predominate, as there is also evidence that mTORC1 activity in these axons contributes to neuropathic pain (Géranton et al., 2009). While continuing research is still explaining the molecular details of how mTORC1 controls nociceptor and dorsal horn neuron plasticity, it is clear that mTORC1 is a critical molecular signaling hub underlying pathological pain. Mitogen activated protein kinase (MAPK) is another signaling pathway linking extracellular signals to translation in neurons, including nociceptors.
The MAPK isoforms extracellular signalregulated kinases (ERK) and p38, which play important roles in nociceptor excitability and synaptic plasticity in the CNS, phosphorylate eIF4E at Ser 209 via MAP kinase interacting kinase (Pyronnet et al., 1999).

Two MNK isoforms are noticed in mammalian genomes and both are expressed in the nervous system. MNK-enhanced phosphorylation of eIF4E is thought to regulate the translation of a subset of mRNAs (Furic et al., 2010). mRNAs whose translation is decreased in the absence of eIF4E phosphorylation encode cytokines, chemokines, and other plasticity-associated proteins (Herdy et al., 2012). Among these mRNAs is the matrix metalloprotease isoform 9 (MMP9) (Gkogkas et al., 2014), which is located in the DRG. It is organized by injury and/or by chronic opioid exposure, and is complicated in pathological pain (Ji et al., 2009; Kawasaki et al., 2008; Liu et al., 2012). ERK or p38 signaling to eIF4E through MNK1/2 is also involved in the progress of pain plasticity by endogenous factors that signal via this pathway through their similar cell surface receptors.

\section{Symptomatic treatment}

The choice of first-line and second-line agents differs between guidelines due to fundamental methodological differences in the criteria employed to define efficacy. However, most guidelines recommend usually using tricyclic agents (TCAs), serotonin-norepinephrine reuptake inhibitors (SNRIs) or $\gamma$-aminobutyric acid (GABA) analogues (gabapentin or pregabalin) as first-line agents followed by opioids and topical treatments (Spallone, 2012). Nonsteroidal anti-inflammatory drugs (NSAIDs) are often prescribed for short-term analgesia, primarily when is seemed not to be $\mathrm{DN}$.

\section{Antidepressants}

Antidepressants pregabalin/gabapentin

along with (voltage-dependent calcium channels $\alpha 2 \delta$ subunit ligands) are considered as first-line drugs of choice for neuropathic pain (Attal et al., 2010; Dworkin et al., 2007; Finnerup et al., 2010, 2015). Specific antidepressants with analgesic effects include tricyclic antidepressants (TCA), which are serotonin noradrenaline reuptake inhibitors (SNRI), also are known as new antidepressants. 
Table 1: Pharmacological Treatment of Diabetic Peripheral Neuropathy

\begin{tabular}{|c|c|c|}
\hline Medication & Recommended dose & Comment \\
\hline \multicolumn{3}{|l|}{ Antidepressants } \\
\hline Amitriptyline & $25-100 \mathrm{mg}$, at bedtime & $\begin{array}{l}\text { Not recommended over duloxetine or venlafaxine. AEs } \\
\text { include dry mouth, urinary retention, sedation, vertigo, } \\
\text { constipation. Monitor BP, heart rate, ECG before and during } \\
\text { initiation; weight; mental status. Avoid use in patients older } \\
\text { than } 60 \text { years of age. }\end{array}$ \\
\hline Desipramine & $\begin{array}{l}10-25 \mathrm{mg} \text { titrated to } \\
100-150 \mathrm{mg} \text { at bedtime }\end{array}$ & $\begin{array}{l}\text { Safer alternative to amitriptyline (less-severe anticholinergic } \\
\text { effects, less sedation). Preferred TCA for elderly patients. } \\
\text { AEs include dry mouth, sedation, dizziness, confusion, } \\
\text { orthostatic constipation, urinary retention, blurred vision, } \\
\text { weight gain, arrythmias. Monitor BP, heart rate, ECG before } \\
\text { and during initiation; weight; mental status. }\end{array}$ \\
\hline $\begin{array}{l}\text { Duloxetine } \\
\text { (Cymbalta) }\end{array}$ & $60 \mathrm{mg} / \mathrm{day}$ & $\begin{array}{l}\text { First drug approved for treatment of DPN (2004). AEs } \\
\text { include nausea, somnolence, hyperhidrosis, anorexia, } \\
\text { vomiting, constipation, fatigue, dry mouth. Monitor BP, } \\
\text { mental status, liver enzymes. Avoid use in hepatic } \\
\text { impairment; avoid use with } \mathrm{CrCl}<30 \mathrm{~mL} / \mathrm{min} \text {. }\end{array}$ \\
\hline Venlafaxine & $75-225 \mathrm{mg} /$ day & $\begin{array}{l}\text { AEs include nausea, somnolence, ECG changes. Monitor BP, } \\
\text { cholesterol, heart rate. May be added to gabapentin for better } \\
\text { response. }\end{array}$ \\
\hline \multicolumn{3}{|l|}{ Anticonvulsants } \\
\hline Carbamazepine & $\begin{array}{l}600 \mathrm{mg} / \mathrm{day}(200 \mathrm{mg} \\
\mathrm{TID}) \text { to } 800 \mathrm{mg} \text { day } \\
(200 \mathrm{mg} \text { QID) } 60,91\end{array}$ & $\begin{array}{l}\text { AEs include agitation, dry mouth, sedation, ataxia, nausea, } \\
\text { vomiting, blurred vision, confusion, fatigue, nystagmus, } \\
\text { aplastic anemia (rare). Monitor CBC with platelet count, } \\
\text { reticulocytes, serum iron, lipid panel, liver function tests, } \\
\text { urinalysis, BUN, serum carbamazepine levels, thyroid } \\
\text { function tests, serum sodium, ophthalmic exams (papillary } \\
\text { reflexes); observe patient for excessive sedation. }\end{array}$ \\
\hline Gabapentin & $\begin{array}{l}900-3,600 \mathrm{mg} / \mathrm{day} \text { in } \\
\text { three divided doses }\end{array}$ & $\begin{array}{l}\text { AEs include dizziness, somnolence, diarrhea, fatigue, GI } \\
\text { upset, peripheral edema. Monitor serum levels of } \\
\text { concomitant antiepileptic therapy. Reduce dosage if GFR < } \\
60 \mathrm{~mL} / \mathrm{min} \text {. }\end{array}$ \\
\hline $\begin{array}{l}\text { Pregabalin } \\
\text { (Lyrica) }\end{array}$ & $\begin{array}{l}150 \mathrm{mg} / \text { day }(50 \mathrm{mg} \\
\text { TID }) \text { to } 300 \mathrm{mg} / \text { day } \\
(100 \mathrm{mg} \text { TID })\end{array}$ & $\begin{array}{l}\text { Second agent approved for treatment of DPN (2004). AEs } \\
\text { include somnolence, dizziness, peripheral edema, weight } \\
\text { gain. Monitor degree of sedation, symptoms of myopathy or } \\
\text { ocular disturbance, weight gain/edema, creatine } \\
\text { phosphokinase, skin integrity (in diabetic patients). } \\
\text { Treatment may lead to physical or psychological dependence. }\end{array}$ \\
\hline Valproate sodium & $\begin{array}{l}500-1,200 \mathrm{mg} / \mathrm{day} \text { in } \\
\text { two or three divided } \\
\text { doses }\end{array}$ & $\begin{array}{l}\text { AEs include elevated liver enzymes, nausea. Monitor liver } \\
\text { enzymes, CBC with platelet count. }\end{array}$ \\
\hline \multicolumn{3}{|l|}{ Opioids } \\
\hline Morphine sulfate & $15-30 \mathrm{mg}$ every 12 to & $\begin{array}{l}\text { Typical opioid effects should be expected (e.g., constipation, } \\
\text { somnolence, dizziness, nausea, vomiting, itchiness). Chronic }\end{array}$ \\
\hline
\end{tabular}




\begin{tabular}{|c|c|c|}
\hline (MS Contin) & 24 hours & $\begin{array}{l}\text { use may lead to tolerance, frequent dose escalation, and } \\
\text { hyperalgesia. Data are insufficient to recommend this drug } \\
\text { over oxycodone, dextromethorphan, or tramadol. }\end{array}$ \\
\hline $\begin{array}{l}\text { Oxycodone } \\
\text { (OxyContin) }\end{array}$ & $\begin{array}{l}\text { Maximum dosage: } 120 \\
\text { mg/day in two divided } \\
\text { doses of } \mathrm{CR} \\
\text { formulation }\end{array}$ & $\begin{array}{l}\text { Typical opioid effects should be expected (e.g., constipation, } \\
\text { somnolence, dizziness, nausea, vomiting, itchiness). Chronic } \\
\text { use may lead to tolerance, frequent dose escalation, and } \\
\text { hyperalgesia. Data are insufficient to recommend this drug } \\
\text { over dextromethorphan, morphine sulfate, or tramadol. }\end{array}$ \\
\hline \multicolumn{3}{|c|}{ Opioid-Like Analgesics } \\
\hline Dextromethorphan & $\begin{array}{l}400 \mathrm{mg} / \text { day in four } \\
\text { divided doses }\end{array}$ & $\begin{array}{l}\text { Dissociative anesthetic with powerful psychedelic effects at } \\
\text { high doses. Primary AE is sedation (at recommended doses). } \\
\text { Data are insufficient to recommend this drug over oxycodone, } \\
\text { morphine sulfate, or tramadol. }\end{array}$ \\
\hline $\begin{array}{l}\text { Tapentadol } \\
\text { (Nucynta ER) }\end{array}$ & 50-250 mg BID & $\begin{array}{l}\text { Third agent approved for DPN treatment (2012). AEs include } \\
\text { nausea, dizziness, somnolence, constipation, vomiting, } \\
\text { headache. Potential for addiction, abuse, misuse; life- } \\
\text { threatening respiratory depression; neonatal opioid } \\
\text { withdrawal syndrome; interaction with alcohol. }\end{array}$ \\
\hline Tramadol & $\begin{array}{l}210 \mathrm{mg} / \mathrm{day} \text { in two or } \\
\text { four divided doses }\end{array}$ & $\begin{array}{l}\text { AEs include nausea, sedation, constipation, headache, dry } \\
\text { mouth, urinary retention, confusion, tremor, seizures. Monitor } \\
\text { respiratory rate, BP, heart rate, signs of tolerance or abuse. } \\
\text { Data are insufficient to recommend this drug over oxycodone, } \\
\text { morphine sulfate, or dextromethorphan }\end{array}$ \\
\hline \multicolumn{3}{|c|}{ Topical Medications } \\
\hline $\begin{array}{l}\text { Capsaicin (cream) } \\
\text { (Trixaicin HP) }\end{array}$ & $0.075 \%$ TID or QID. & $\begin{array}{l}\text { May be used as adjunct to oral medications. AEs include } \\
\text { localized stinging, burning, and itching; coughing; sneezing; } \\
\text { rash. Monitor skin breakdown. }\end{array}$ \\
\hline $\begin{array}{l}\text { Lidocaine patch } \\
\text { (Lidoderm) }\end{array}$ & $\begin{array}{l}\text { Maximum of three } 5 \% \\
\text { medicated patches } \\
\text { applied once for up to } \\
12 \text { hours within a } 24- \\
\text { hour period. }\end{array}$ & $\begin{array}{l}\text { May be used as adjunct to oral medications. Key AEs include } \\
\text { application-site reactions (e.g., blisters, bruising, burning } \\
\text { sensation, depigmentation, dermatitis, discoloration, edema, } \\
\text { erythema, exfoliation). }\end{array}$ \\
\hline \multicolumn{3}{|c|}{$\begin{array}{l}\mathrm{AE}=\text { adverse event; } \mathrm{AWP}=\text { average wholesale price; } \mathrm{BID}=\mathrm{twice} \text { daily; } \mathrm{BP}=\text { blood pressure; } \mathrm{BUN}=\text { blood urea } \\
\text { nitrogen; } \mathrm{CBC}=\text { complete blood count; } \mathrm{CR}=\text { controlled release; } \mathrm{CrCl}=\text { creatinine clearance; } \mathrm{DPN}=\text { diabetic peripheral } \\
\text { neuropathy; } \mathrm{ECG}=\text { electrocardiogram; } \mathrm{ER}=\text { extended release } \mathrm{GI}=\text { gastrointestinal; } \mathrm{GFR}=\text { glomerular filtration rate; } \\
\mathrm{QID}=\text { four times daily; } \mathrm{TCA}=\text { tricyclic antidepressant } \text { TID = three times daily }\end{array}$} \\
\hline
\end{tabular}

Prolonged pain causes anxiety accompanied by an advanced depressive state and enhanced pain sensations. Therefore, antidepressant medications may be effective against chronic pain by their actions to improve the depressive state. Antidepressants decrease neuropathic pain, however, even when the patient is not in a depressive state (Fishbain et al., 1998). In addition, the pharmacological effects of antidepressants on depression usually take approximately two to four weeks to be observed from the time the drug is first taken, however the analgesic effects on chronic pain noticeable in as little as few days to one week (Onghena and Van Houdenhove, 1992). Thus, the analgesic effects of antidepressants on chronic pain expected involve a mechanism different from that producing their antidepressive effects. 
The pharmacologic effects of antidepressants inhibit the reuptake of noradrenaline and serotonin (5-HT) neurotransmitter by binding to their transporters consequently levels of NA and 5-HT in the synaptic cleft (Berton and Nestler, 2006; Dharmshaktu et al., 2012; Micó et al., 2006; Sindrup et al., 2005).

An antidepressant that impedes reuptake of both noradrenaline and 5-HT has superior analgesic effects than a drug that selectively inhibits reuptake of only one of these neurotransmitters. Noradrenaline plays a greater role than 5-HT in the analgesic action through its action on $\alpha_{2}$-adrenergic receptors.

The $\alpha_{2}$-adrenergic receptors in the dorsal horn of the spinal cord are coupled to the inhibitory $\mathrm{G}$ protein, which inhibits the presynaptic voltage-gated $\mathrm{Ca}^{2+}$ channels in the dorsal horn of the spinal cord that stops the release of excitatory neurotransmitters from primary afferent fibers. Moreover, G proteincoupled inwardly rectifying $\mathrm{K}^{+}$channels are opened on the post-synaptic spinal cord dorsal horn cells, the cell membranes are hyperpolarized, and excitability is reduced (Pan et al., 2008).

\section{Calcium Channel $\alpha 2-\delta$ Ligands (Gabapentin \& Pregabalin)}

Both Gabapentin and pregabalin bind to voltagegated calcium channels at the $\alpha 2-\delta$ subunit and inhibit neurotransmitter release. They have shown efficacy vs placebo in several NP conditions (Dworkin et al., 2007; Finnerup et al., 2005). Although gabapentin and pregabalin have few drug interactions, both can cause dose-dependent vertigo and drowsiness, which can be diminished by beginning with lower dosages and increasing carefully. Both medications also need dosage restriction in patients with renal inefficiency, and dosage modifications can be prepared in relation to creatinine clearance.

Antidepressants increase noradrenaline via blocking of noradrenaline transporters at the terminal of the descending noradrenergic fiber from the locus coeruleus. Noradrenaline inhibits acute pain through $\alpha 2$-adrenergic receptors by pre-synaptic (inhibit neurotransmitters release) and post-synaptic (hyperpolarize cell membranes) mechanisms. In neuropathic pain states, however, $\alpha 2$-adrenergic receptors in the cholinergic interneurons change from inhibitory to excitatory through G-protein

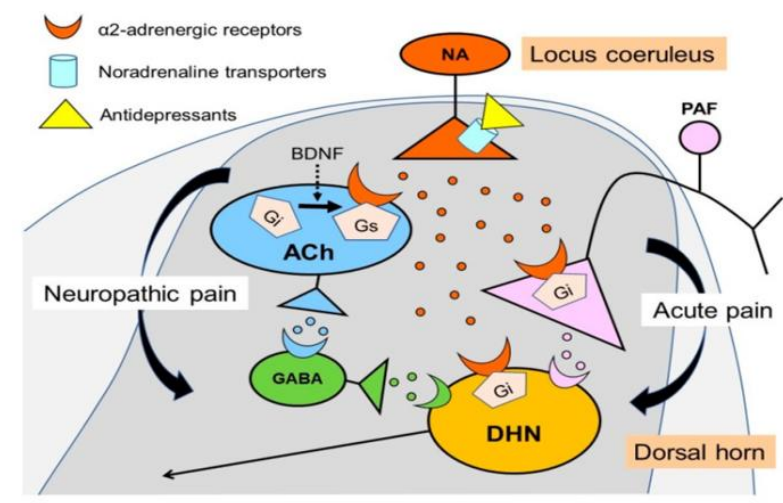

Figure 3. Schematic illustration of analgesic effects of antidepressants and noradrenaline in the dorsal horn of the spinal cord.

switch (from Gi to Gs) by the effect of brainderived neurotrophic factor (BDNF) increasing after nerve injury. Released acetylcholine bind to muscarinic receptors, by which produce analgesia thorough GABA release. PAF; primary afferent fibers, NA; noradrenaline, DHN; dorsal horn neurons, ACh; acetylcholine, Red circle; noradrenaline, Blue circle; acetylcholine, Green circle; GABA, Pink circle; excitatory neurotransmitters.

\section{Alpha-lipoic acid \\ Alpha-lipoic acid augmented the reduced glutathione (GSH) in vivo and in vitro (Brownlee et al., 1988; Nagamatsu et al., 1995). GSH is a vital endogenous antioxidant. That play an important role in redox-dependent mechanisms of several cellular processes (Low et al., 1997; Mitsui et al., 1999; Nagamatsu et al., 1995). \\ Alpha-lipoic acid is a free radical scavenger of peripheral nerve both in vitro and in vivo (Kozlov et al., 1999; Podda et al., 1994). Alpha-lipoic acid has further actions such as enhancing nerve growth factor and stimulating fiber regeneration (Dimpfel et al., 1990; Murase et al., 1993).}

\section{Vitamin B}

Deficiency of vitamin B12 (also known as cobalamin) resulting in a lack of methylcobalamin, has been related with significant neurological pathology, especially peripheral neuropathy (Andrès et al., 2004; Head, 2006). It is also accompanied with the onset of diabetic neuropathy. In patients with DPN, vitamin B12 deficiency may be triggered by the use of antidiabetic agents such as metformin (Liu et al., 2006; Ting et al., 2006). 
Vitamin B12 and its coenzymes have been used to reduce pain. In some countries, vitamin B12 is categorized as an analgesic drug. It has been proposed that vitamin B12 may increase the availability and efficacy of noradrenaline and 5hydroxytryptamine in the descending inhibitory nociceptive system (Jurna, 1998).

In animal models, morphological and histological evidence has also revealed that long-term administration of methylcobalamin enhances the synthesis and regeneration of myelin (Okada et al., 2010).

\section{Donepezil}

Donepezil, a piperidine-based, reversible acetylcholinesterase inhibitor, is the most commonly pharmacological agent for the treatment of Alzheimer's disease (AD).

The first category of drugs approved by the US FDA for AD was cholinesterase inhibitors. Though donepezil's primary mechanism of action is

\section{References}

Afsari, Z.H., Renno, W.M., and Abd-El-Basset, E. 2008. Alteration of glial fibrillary acidic proteins immunoreactivity in astrocytes of the spinal cord diabetic rats. Anat. Rec. Hoboken NJ 2007 291, 390-399.

Arora, S., Pomposelli, F., LoGerfo, F.W., and Veves, A. 2002. Cutaneous microcirculation in the neuropathic diabetic foot improves significantly but not completely after successful lower extremity revascularization. J. Vasc. Surg. 35, 501-505.

Asiedu, M.N., Dussor, G., and Price, T.J. 2016. Targeting AMPK for the Alleviation of Pathological Pain. EXS 107, 257-285.

Aslam, A., Singh, J., and Rajbhandari, S. 2014. Pathogenesis of painful diabetic neuropathy. Pain Res. Treat. 2014, 412041.

Bai, H.-P., Liu, P., Wu, Y.-M., Guo, W.-Y., Guo, Y.-X., and Wang, X.-L. 2014. Activation of spinal GABAB receptors normalizes N-methyl-Daspartate receptor in diabetic neuropathy. J. Neurol. Sci. 341, 68-72.

Baron, R., Binder, A., and Wasner, G. 2010. Neuropathic pain: diagnosis, pathophysiological supposed to be enzyme inhibition, so stimulating central cholinergic neurotransmission, it may have further actions, such as combating glutamate-induced excitotoxicity (Takada et al., 2003) and prompting amyloid processing and deposition (Racchi et al., 2004; Svensson and Nordberg, 1998), which more directly influence the pathophysiology of AD.

Donepezil, as an acetylcholinesterase (AChE) inhibitor, exerts an additional beneficial effect via the nicotinic acetylcholine receptor (nAChR)mediated cascade (Takada et al., 2003). ACh receptors provide neuroprotection against glutamate-induced excitotoxicity by stimulating the phosphatidylinositol-3 kinase (PI3K)/protein kinase B (Akt) pathway (Asomugha et al., 2010). The stimulation of nAChRs could attenuate the downregulation of the surface level of glutamate receptors containing the subunits NR1/2A and NMDA receptor activity (Shen et al., 2010).

mechanisms, and treatment. Lancet Neurol. 9, 807-819.

Brownlee, M. 2001. Biochemistry and molecular cell biology of diabetic complications. Nature $414,813-820$

Cameron, N.E., Eaton, S.E., Cotter, M.A., and Tesfaye, S. 2001. Vascular factors and metabolic interactions in the pathogenesis of diabetic neuropathy. Diabetologia 44, 1973-1988.

Chalk, C., Benstead, T.J., and Moore, F. 2007. Aldose reductase inhibitors for the treatment of diabetic polyneuropathy. Cochrane Database Syst. Rev. CD004572.

Chen, S.-R., and Pan, H.-L. 2002. Hypersensitivity of spinothalamic tract neurons associated with diabetic neuropathic pain in rats. J. Neurophysiol. 87, 2726-2733.

Cheng, K.-I., Wang, H.-C., Chuang, Y.-T., Chou, C.-W., Tu, H.-P., Yu, Y.-C., Chang, L.-L., and Lai, C.-S. 2014. Persistent mechanical allodynia positively correlates with an increase in activated microglia and increased P-p38 mitogen-activated protein kinase activation in streptozotocininduced diabetic rats. Eur. J. Pain Lond. Engl. 18, 162-173. 
Crown, E.D. 2012. The role of mitogen activated protein kinase signaling in microglia and neurons in the initiation and maintenance of chronic pain. Exp. Neurol. 234, 330-339.

Cunha, J.M., Jolivalt, C.G., Ramos, K.M., Gregory, J.A., Calcutt, N.A., and Mizisin, A.P. 2008. Elevated lipid peroxidation and DNA oxidation in nerve from diabetic rats: effects of aldose reductase inhibition, insulin, and neurotrophic factors. Metabolism. 57, 873-881.

Doupis, J., Lyons, T.E., Wu, S., Gnardellis, C., Dinh, T., and Veves, A. 2009. Microvascular reactivity and inflammatory cytokines in painful and painless peripheral diabetic neuropathy. J. Clin. Endocrinol. Metab. 94, 2157-2163.

Eaton, S.E.M., Harris, N.D., Ibrahim, S., Patel, K.A., Selmi, F., Radatz, M., Ward, J.D., and Tesfaye, S. 2003. Increased sural nerve epineurial blood flow in human subjects with painful diabetic neuropathy. Diabetologia 46, 934-939.

Fuchs, D., Birklein, F., Reeh, P.W., and Sauer, S.K. 2010. Sensitized peripheral nociception in experimental diabetes of the rat. Pain 151, 496505.

Furic, L., Rong, L., Larsson, O., Koumakpayi, I.H., Yoshida, K., Brueschke, A., Petroulakis, E., Robichaud, N., Pollak, M., Gaboury, L.A., et al. 2010. eIF4E phosphorylation promotes tumorigenesis and is associated with prostate cancer progression. Proc. Natl. Acad. Sci. U. S. A. 107, 14134-14139.

Géranton, S.M., Jiménez-Díaz, L., Torsney, C., Tochiki, K.K., Stuart, S.A., Leith, J.L., Lumb, B.M., and Hunt, S.P. 2009. A rapamycin-sensitive signaling pathway is essential for the full expression of persistent pain states. J. Neurosci. Off. J. Soc. Neurosci. 29, 15017-15027.

Gingras, A.C., Raught, B., and Sonenberg, N. 2004. mTOR signaling to translation. Curr. Top. Microbiol. Immunol. 279, 169-197.

Gkogkas, C.G., Khoutorsky, A., Cao, R., Jafarnejad, S.M., Prager-Khoutorsky, M., Giannakas, N., Kaminari, A., Fragkouli, A., Nader, K., Price, T.J., et al. 2014. Pharmacogenetic inhibition of eIF4E-dependent Mmp9 mRNA translation reverses fragile $\mathrm{X}$ syndrome-like phenotypes. Cell Rep. 9, 1742-1755.

Hardie, D.G. 2007. AMP-activated/SNF1 protein kinases: conserved guardians of cellular energy. Nat. Rev. Mol. Cell Biol. 8, 774-785.

Herdy, B., Jaramillo, M., Svitkin, Y.V., Rosenfeld, A.B., Kobayashi, M., Walsh, D., Alain, T., Sean, P., Robichaud, N., Topisirovic, I., et al. 2012. Translational control of the activation of transcription factor NF- $\mathrm{kB}$ and production of type I interferon by phosphorylation of the translation factor eIF4E. Nat. Immunol. 13, 543-550.

Inkster, M.E., Cotter, M.A., and Cameron, N.E. 2007. Treatment with the xanthine oxidase inhibitor, allopurinol, improves nerve and vascular function in diabetic rats. Eur. J. Pharmacol. 561, 63-71.

Jelicic Kadic, A., Boric, M., Vidak, M., Ferhatovic, L., and Puljak, L. 2014. Changes in epidermal thickness and cutaneous innervation during maturation in long-term diabetes. J. Tissue Viability 23, 7-12.

Ji, R.-R., Xu, Z.-Z., Wang, X., and Lo, E.H. 2009. Matrix metalloprotease regulation of neuropathic pain. Trends Pharmacol. Sci. 30, 336-340.

Jiménez-Díaz, L., Géranton, S.M., Passmore, G.M., Leith, J.L., Fisher, A.S., Berliocchi, L., Sivasubramaniam, A.K., Sheasby, A., Lumb, B.M., and Hunt, S.P. 2008. Local translation in primary afferent fibers regulates nociception. PloS One 3, e1961.

Jin, H.Y., Lee, K.A., Song, S.K., Liu, W.J., Choi, J.H., Song, C.H., Baek, H.S., and Park, T.S. 2012. Sulodexide prevents peripheral nerve damage in streptozotocin induced diabetic rats. Eur. J. Pharmacol. 674, 217-226.

Kawasaki, Y., Xu, Z.-Z., Wang, X., Park, J.Y., Zhuang, Z.-Y., Tan, P.-H., Gao, Y.-J., Roy, K., Corfas, G., Lo, E.H., et al. 2008. Distinct roles of matrix metalloproteases in the early- and latephase development of neuropathic pain. Nat. Med. 14, 331-336. 
Kettenmann, H., and Verkhratsky, A. 2008. Neuroglia: the 150 years after. Trends Neurosci. 31, 653-659.

Kim, J., Yoon, M.Y., Choi, S.L., Kang, I., Kim, S.S., Kim, Y.S., Choi, Y.K., and Ha, J. 2001. Effects of stimulation of AMP-activated protein kinase on insulin-like growth factor 1- and epidermal growth factor-dependent extracellular signal-regulated kinase pathway. J. Biol. Chem. 276, 19102-19110.

Kim, J.H., Roberts, D.S., Hu, Y., Lau, G.C., Brooks-Kayal, A.R., Farb, D.H., and Russek, S.J. 2012. Brain-derived neurotrophic factor uses CREB and Egr3 to regulate NMDA receptor levels in cortical neurons. J. Neurochem. 120, 210-219.

Li, J.-Q., Chen, S.-R., Chen, H., Cai, Y.-Q., and Pan, H.-L. 2010. Regulation of increased glutamatergic input to spinal dorsal horn neurons by mGluR5 in diabetic neuropathic pain. J. Neurochem. 112, 162-172.

Liu, Y.-C., Berta, T., Liu, T., Tan, P.-H., and Ji, R.R. 2012. Acute morphine induces matrix metalloproteinase-9 up-regulation in primary sensory neurons to mask opioid-induced analgesia in mice. Mol. Pain 8, 19.

Maier, C., Baron, R., Tölle, T.R., Binder, A., Birbaumer, N., Birklein, F., Gierthmühlen, J., Flor, H., Geber, C., Huge, V., et al. 2010. Quantitative sensory testing in the German Research Network on Neuropathic Pain (DFNS): somatosensory abnormalities in 1236 patients with different neuropathic pain syndromes. Pain 150, 439-450.

Malik, R.A., Tesfaye, S., Thompson, S.D., Veves, A., Sharma, A.K., Boulton, A.J., and Ward, J.D. 1993. Endoneurial localisation of microvascular damage in human diabetic neuropathy. Diabetologia 36, 454-459.

McDaniel, M.L., Marshall, C.A., Pappan, K.L., and Kwon, G. 2002. Metabolic and autocrine regulation of the mammalian target of rapamycin by pancreatic beta-cells. Diabetes 51, 2877-2885.

Melemedjian, O.K., Asiedu, M.N., Tillu, D.V., Peebles, K.A., Yan, J., Ertz, N., Dussor, G.O., and Price, T.J. 2010. IL-6- and NGF-induced rapid control of protein synthesis and nociceptive plasticity via convergent signaling to the eIF4F complex. J. Neurosci. Off. J. Soc. Neurosci. 30, 15113-15123.

Melemedjian, O.K., Asiedu, M.N., Tillu, D.V., Sanoja, R., Yan, J., Lark, A., Khoutorsky, A., Johnson, J., Peebles, K.A., Lepow, T., et al. 2011. Targeting adenosine monophosphate-activated protein kinase (AMPK) in preclinical models reveals a potential mechanism for the treatment of neuropathic pain. Mol. Pain 7, 70.

Melemedjian, O.K., Tillu, D.V., Asiedu, M.N., Mandell, E.K., Moy, J.K., Blute, V.M., Taylor, C.J., Ghosh, S., and Price, T.J. 2013. BDNF regulates atypical PKC at spinal synapses to initiate and maintain a centralized chronic pain state. Mol. Pain 9, 12.

Mijnhout, G.S., Alkhalaf, A., Kleefstra, N., and Bilo, H.J.G. 2010. Alpha lipoic acid: a new treatment for neuropathic pain in patients with diabetes? Neth. J. Med. 68, 158-162.

Mika, J., Zychowska, M., Popiolek-Barczyk, K., Rojewska, E., and Przewlocka, B. 2013. Importance of glial activation in neuropathic pain. Eur. J. Pharmacol. 716, 106-119.

Oates, P.J. 2002. Polyol pathway and diabetic peripheral neuropathy. Int. Rev. Neurobiol. 50, 325-392.

Obara, I., Tochiki, K.K., Géranton, S.M., Carr, F.B., Lumb, B.M., Liu, Q., and Hunt, S.P. 2011. Systemic inhibition of the mammalian target of rapamycin (mTOR) pathway reduces neuropathic pain in mice. Pain 152, 2582-2595.

Obrosova, I.G., Mabley, J.G., Zsengellér, Z., Charniauskaya, T., Abatan, O.I., Groves, J.T., and Szabó, C. 2005. Role for nitrosative stress in diabetic neuropathy: evidence from studies with a peroxynitrite decomposition catalyst. FASEB J. Off. Publ. Fed. Am. Soc. Exp. Biol. 19, 401-403.

Oyibo, S.O., Prasad, Y.D.M., Jackson, N.J., Jude, E.B., and Boulton, A.J.M. 2002. The relationship between blood glucose excursions and painful diabetic peripheral neuropathy: a pilot study. Diabet. Med. J. Br. Diabet. Assoc. 19, 870-873.

Ozkul, A., Ayhan, M., Yenisey, C., Akyol, A., 
Guney, E., and Ergin, F.A. 2010. The role of oxidative stress and endothelial injury in diabetic neuropathy and neuropathic pain. Neuro Endocrinol. Lett. 31, 261-264.

Pavy-Le Traon, A., Fontaine, S., Tap, G., Guidolin, B., Senard, J.-M., and Hanaire, H. 2010. Cardiovascular autonomic neuropathy and other complications in type 1 diabetes. Clin. Auton. Res. Off. J. Clin. Auton. Res. Soc. 20, 153-160.

Pérez-Garci, E., Gassmann, M., Bettler, B., and Larkum, M.E. 2006. The GABAB1b isoform mediates long-lasting inhibition of dendritic $\mathrm{Ca} 2+$ spikes in layer 5 somatosensory pyramidal neurons. Neuron 50, 603-616.

Price, T.J., Rashid, M.H., Millecamps, M., Sanoja, R., Entrena, J.M., and Cervero, F. 2007. Decreased nociceptive sensitization in mice lacking the fragile $\mathrm{X}$ mental retardation protein: role of mGluR $1 / 5$ and mTOR. J. Neurosci. Off. J. Soc. Neurosci. 27, 13958-13967.

Pyronnet, S., Imataka, H., Gingras, A.C., Fukunaga, R., Hunter, T., and Sonenberg, N. 1999. Human eukaryotic translation initiation factor $4 \mathrm{G}$ (eIF4G) recruits mnk1 to phosphorylate eIF4E. EMBO J. 18, 270-279.

Quattrini, C., and Tesfaye, S. 2003. Understanding the impact of painful diabetic neuropathy. Diabetes Metab. Res. Rev. 19 Suppl 1, S2-8.

Quattrini, C., Harris, N.D., Malik, R.A., and Tesfaye, S. 2007. Impaired skin microvascular reactivity in painful diabetic neuropathy. Diabetes Care 30, 655-659.

Said, G., Baudoin, D., and Toyooka, K. 2008. Sensory loss, pains, motor deficit and axonal regeneration in length-dependent diabetic polyneuropathy. J. Neurol. 255, 1693-1702.

Sanchez, A.P., and Sharma, K. 2009. Transcription factors in the pathogenesis of diabetic nephropathy. Expert Rev. Mol. Med. 11, e13.

Schreiber, A.K., Nones, C.F., Reis, R.C., Chichorro, J.G., and Cunha, J.M. 2015. Diabetic neuropathic pain: Physiopathology and treatment. World J. Diabetes 6, 432-444.

Sheetz, M.J., and King, G.L. 2002. Molecular understanding of hyperglycemia's adverse effects for diabetic complications. JAMA 288, 25792588.

Shun, C.-T., Chang, Y.-C., Wu, H.-P., Hsieh, S.C., Lin, W.-M., Lin, Y.-H., Tai, T.-Y., and Hsieh, S.-T. 2004. Skin denervation in type 2 diabetes: correlations with diabetic duration and functional impairments. Brain J. Neurol. 127, 1593-1605.

Sodickson, D.L., and Bean, B.P. 1996. GABAB receptor-activated inwardly rectifying potassium current in dissociated hippocampal CA3 neurons. J. Neurosci. Off. J. Soc. Neurosci. 16, 63746385 .

Sonenberg, N. 2008. eIF4E, the mRNA capbinding protein: from basic discovery to translational researchThis paper is one of a selection of papers published in this Special Issue, entitled CSBMCB - Systems and Chemical Biology, and has undergone the Journal's usual peer review process. Biochem. Cell Biol. 86, 178-183.

Sorensen, L., Molyneaux, L., and Yue, D.K. 2006. The relationship among pain, sensory loss, and small nerve fibers in diabetes. Diabetes Care $29,883-887$.

Spallone, V. 2012. Management of painful diabetic neuropathy: guideline guidance or jungle? Curr. Diab. Rep. 12, 403-413.

Suzuki, N., Hasegawa-Moriyama, M., Takahashi, Y., Kamikubo, Y., Sakurai, T., and Inada, E. 2011. Lidocaine attenuates the development of diabetic-induced tactile allodynia by inhibiting microglial activation. Anesth. Analg. 113, 941946.

Tang, J., Wingerchuk, D.M., Crum, B.A., Rubin, D.I., and Demaerschalk, B.M. 2007. Alpha-lipoic acid may improve symptomatic diabetic polyneuropathy. The Neurologist 13, 164-167.

Taylor, A., Westveld, A.H., Szkudlinska, M., Guruguri, P., Annabi, E., Patwardhan, A., Price, T.J., and Yassine, H.N. 2013. The use of metformin is associated with decreased lumbar radiculopathy pain. J. Pain Res. 6, 755-763.

Toth, C.C., Jedrzejewski, N.M., Ellis, C.L., and 
Frey, W.H. 2010. Cannabinoid-mediated modulation of neuropathic pain and microglial accumulation in a model of murine type I diabetic peripheral neuropathic pain. Mol. Pain 6, 16.

Tsuda, M., Ueno, H., Kataoka, A., Tozaki-Saitoh, H., and Inoue, K. 2008. Activation of dorsal horn microglia contributes to diabetes-induced tactile allodynia via extracellular signal-regulated protein kinase signaling. Glia 56, 378-386.

Vareniuk, I., Pavlov, I.A., Drel, V.R., Lyzogubov, V.V., Ilnytska, O., Bell, S.R., Tibrewala, J., Groves, J.T., and Obrosova, I.G. 2007. Nitrosative stress and peripheral diabetic neuropathy in leptindeficient (ob/ob) mice. Exp. Neurol. 205, 425-436.

Vydyanathan, A., Wu, Z.-Z., Chen, S.-R., and Pan, H.-L. 2005. A-type voltage-gated $\mathrm{K}+$ currents influence firing properties of isolectin B4-positive but not isolectin B4-negative primary sensory neurons. J. Neurophysiol. 93, 3401-3409.

Wang, S., Kobayashi, K., Kogure, Y., Yamanaka,
H., Yamamoto, S., Yagi, H., Noguchi, K., and Dai, Y. 2018. Negative Regulation of TRPA1 by AMPK in Primary Sensory Neurons as a Potential Mechanism of Painful Diabetic Neuropathy. Diabetes 67, 98-109.

Wang, X.-L., Zhang, H.-M., Chen, S.-R., and Pan, H.-L. 2007. Altered synaptic input and GABAB receptor function in spinal superficial dorsal horn neurons in rats with diabetic neuropathy. J. Physiol. 579, 849-861.

Wodarski, R., Clark, A.K., Grist, J., Marchand, F., and Malcangio, M. 2009. Gabapentin reverses microglial activation in the spinal cord of streptozotocin-induced diabetic rats. Eur. J. Pain Lond. Engl. 13, 807-811.

Ziegler, D., Low, P.A., Litchy, W.J., Boulton, A.J.M., Vinik, A.I., Freeman, R., Samigullin, R., Tritschler, H., Munzel, U., Maus, J., et al. 2011. Efficacy and safety of antioxidant treatment with $\alpha$-lipoic acid over 4 years in diabetic polyneuropathy: the NATHAN 1 trial. Diabetes Care 34, 2054-2060. 